\title{
Inhabiting warm microhabitats and risk-spreading as strategies for survival of a phytophagous insect living in common pastures in the Pyrenees
}

\author{
GREGor STUHLDREHER ${ }^{1}$, LUIS VILLAR ${ }^{2}$ and THOMAS FARTMANN ${ }^{1 *}$ \\ ${ }^{1}$ Department of Community Ecology, Institute of Landscape Ecology, University of Münster, Robert-Koch-Straße 28, \\ 48149 Münster, Germany; e-mails: gregor.stuhldreher@uni-muenster.de; fartmann@uni-muenster.de \\ ${ }^{2}$ Instituto Pirenaico de Ecología, IPE-CSIC, Apdo. 64, 22700 Jaca (Huesca), Spain; e-mail: 1villar@ipe.csic.es
}

Key words. Lepidoptera, Lycaenidae, Satyrium spini, oviposition, batch size, conservation management, grazing, microclimate

\begin{abstract}
The breakdown of the transhumant grazing system in the Spanish Pyrenees has led to a severe decline in the area of pastures. However, in the high mountain zone there are still large areas of species-rich grasslands. The aim of this study was to assess the oviposition preferences of the shrub-feeding Blue-spot hairstreak, Satyrium spini (Denis \& Schiffermüller, 1775), in montane common pastures in the Spanish Pyrenees and recommend a way of managing these grasslands that favours this species. Our study showed that females of $S$. spini laid their eggs on Dwarf buckthorn (Rhamnus pumila Turra) and Alpine buckthorn ( $R$. alpina L.), which are novel host plant records for Spain. A warm microclimate was of crucial importance for egg-laying. Occupied plants grew mostly at sparsely vegetated grassland sites where there were large patches of bare rocks, stones or gravel. Most egg batches were laid close to the ground and $75 \%$ consisted of only one egg. The number of batches per R. pumila plant was higher on east-, southand west-facing slopes than on north-facing slopes. Presence of eggs and the number of egg batches per $R$. pumila plant were best explained by a long sunshine duration. At high altitudes particularly warm microhabitats seem to be more important for $S$. spini than at lower altitudes in Central Europe. We assume that the preference for unusually warm microhabitats is explained by the cold climatic conditions near the altitudinal range limit of the species. That most of the eggs were laid singly and not in small batches as in Central Europe might be a risk-spreading strategy to cope with the harsh climatic conditions and the high inter-annual variation in weather conditions in the high mountain zone in the Pyrenees. The best way to maintain open grasslands for S. spini and other thermophilous grassland species in the high mountain zone of the Pyrenees is to use the traditional combination of sheep and cattle grazing.
\end{abstract}

\section{INTRODUCTION}

During recent decades, the worldwide rate of species extinctions has risen continuously and is now estimated to be 100 to 1000 times higher than the natural background extinction (Pimm et al., 1995). In terrestrial ecosystems, the most important driver of this process is land-use change (Sala et al., 2000). On a global scale it is expected to have the largest impact on biodiversity by the year 2100 and to be even more important than other factors like climate change or nitrogen deposition.

The transition from traditional land-use to modern agriculture mostly entails two contrasting processes: intensified use of productive sites that can be cultivated mechanically and abandonment of marginal land (Foley et al., 2005; Henle et al., 2008; Kleijn et al., 2009). Both phenomena often have adverse effects on species richness. Intense exploitation of agricultural land occurs mainly in lowlands with fertile soils and sufficient rainfall or irrigation water, whereas abandonment of land is typical of mountain areas (Caraveli, 2000; MacDonald et al., 2000). Declines in habitat and species diversity due to cessation of traditional land use have been reported for several European mountain ranges (MacDonald et al., 2000; Tasser \& Tappeiner, 2002; Bezák \& Halada, 2010).
The causes and consequences of land-use change are particularly well studied in the Spanish Pyrenees (GarcíaRuiz \& Lasanta-Martínez, 1990; García-Ruiz et al., 1996; Poyatos et al., 2003; Lasanta-Martínez et al., 2005; Vicente-Serrano et al., 2005). The traditional agricultural systems have undergone dramatic changes since the beginning of the 20th century (García-Ruiz \& LasantaMartínez, 1990; Lasanta-Martínez et al., 2005). Decreases in rural populations, losses of winter pastures in the Ebro basin and the development of tourism, which partially replaced agriculture as the main source of revenue, have led to the breakdown of the transhumance system (= seasonal movement of shepherds and their livestock). This in turn caused a severe decline in sheep numbers which in some areas decreased by $90 \%$ in the course of the last century and many summer pastures have become abandoned, particularly those that were less productive and remote. However, at high altitude in the Pyrenees there are still large areas of grassland with a very diverse fauna and flora (Gómez et al., 2003; García-González et al., 2008). Our study area in the upper part of the Aísa Valley (western Spanish Pyrenees) is such a biodiversity hotspot (Isern-Vallverdú, 1990; García-González et al., 1991).

Butterflies are a charismatic and species-rich insect group. Because they respond rapidly to environmental

\footnotetext{
* Author for correspondence.
} 


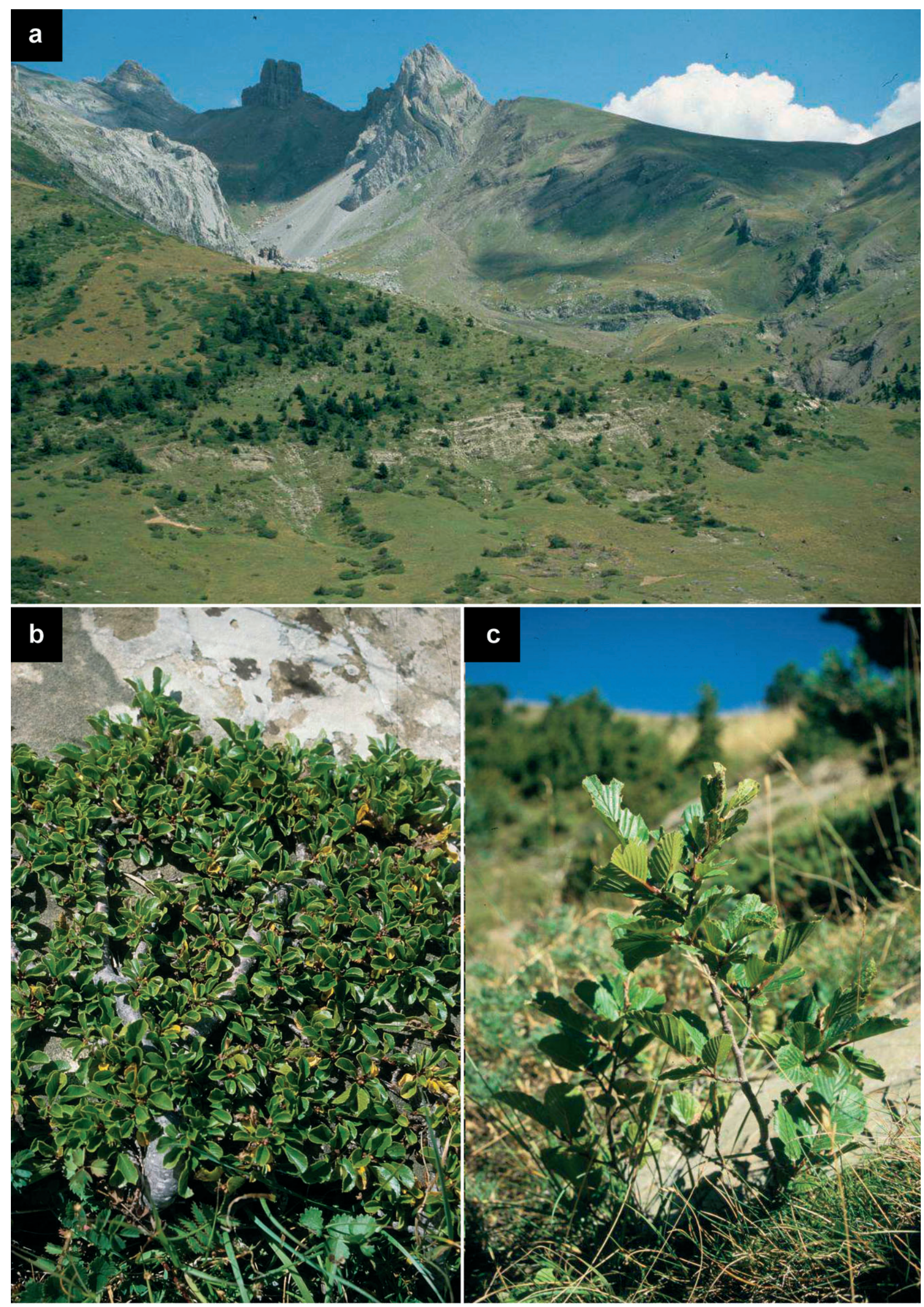

Fig. 1. View of the common pastures in the study area (a), Rhammus pumila (b) and R. alpina (c) host plants of Satyrium spini. 
changes they are often used as bioindicators (Watt \& Boggs, 2003; van Swaay et al., 2006). The most important biotope for European butterflies, including threatened species, is grassland (van Swaay et al., 2006). The Bluespot hairstreak, Satyrium spini (Denis \& Schiffermüller, 1775), is a monophagous species that in temperate lowlands (Ebert \& Rennwald, 1991; Fartmann, 2004; Hermann, 2007) and high mountain ranges (Huemer, 2004) is associated with species-rich dry grasslands. Although its host plants (Rhamnus species) are widespread (e.g. Villar et al., 1997) S. spini is not common in the Spanish Pyrenees (Abós Castel, 1988; García-Barros et al., 2004; C. Stefanescu, pers. comm.). Unlike for Central Europe (Weidemann, 1982; Koschuh et al., 2005; Hermann, 2007) there is no information on the oviposition habitats of this species in southern Europe (cf. García-Barros \& Fartmann, 2009), which might explain its scattered distribution throughout the Pyrenees.

The aim of this study was to assess the oviposition preferences of the shrub-feeding hairstreak butterfly S. spini in high mountain common pastures of the Spanish Pyrenees and recommend a way of managing grasslands that favours this species. In particular we considered the following questions:

(i) Which environmental factors determine the egglaying preferences of this species?

(ii) What are the implications for nature conservation in the light of the ongoing agricultural changes in the Pyrenees?

\section{MATERIAL AND METHODS}

\section{Study area}

The study area $\left(42^{\circ} 44^{\prime} \mathrm{N}, 0^{\circ} 35^{\prime} \mathrm{W}\right)$ is located in the western Spanish Pyrenees, about $20 \mathrm{~km}$ north of Jaca (province Huesca) in the Aísa Valley. It is approximately 200 ha in size and situated in the high mountain zone (1470-1780 m a.s.1.) in the eastern part of the Natural Park Valles Occidentales (Sánchez, 2007). The climate is oro-Mediterranean with a mean annual temperature of $5.5^{\circ} \mathrm{C}$, a mean summer temperature of $13.5^{\circ} \mathrm{C}$ and a mean winter temperature of $-0.6^{\circ} \mathrm{C}$ (values given for an altitude of $1780 \mathrm{~m}$ a.s.1.). Mean annual precipitation varies with altitude between 1200 and $2000 \mathrm{~mm}$ (Badía Villas et al., 2002). Within the study area calcareous grasslands used as common pastures for cattle and sheep dominate. These grasslands developed as a result of livestock husbandry with tree cutting or burning and replaced native woodlands (García-Ruiz \& Lasanta-Martínez, 1990). The inclinations and aspects of the hillsides in this valley are very variable. On the steeper slopes there are large areas of bare rocks and sparsely vegetated screes (Fig. 1a).

\section{Study species}

The Blue-spot Hairstreak, Satyrium spini (Denis \& Schiffermüller, 1775), is a lycaenid butterfly with a range extending from South-west, South and Central Europe to Western Asia. It is absent from the British Isles, Scandinavia and the oceanic regions of Central Europe (Ebert \& Rennwald, 1991). S. spini occurs in most parts of the Iberian Peninsula, but mainly in the mountain ranges (García-Barros et al., 2004). S. spini is a univoltine species with a flight period ranging from July to August in the Spanish Pyrenees (Abós Castel, 1988). Females lay their eggs usually in small batches on various species of buckthorn (Rhamnus spp.) (Tolman \& Lewington, 1998;
TABLE 1. List of the parameters included in the microhabitat analyses. GLM - Generalized Linear Model, MWU - MannWhitney $U$ test, $\mathrm{t}-t$ test.

\begin{tabular}{|c|c|c|}
\hline Variable & Factor levels & Statistical method \\
\hline \multicolumn{3}{|l|}{ Response variable } \\
\hline Host plant occupancy & $2^{\mathrm{a}}$ & GLM (Binomial) \\
\hline Egg batches per plant & metric & $\begin{array}{c}\text { GLM } \\
\text { (quasi-Poisson) }\end{array}$ \\
\hline \multicolumn{3}{|l|}{ Predictor variable } \\
\hline \multicolumn{3}{|l|}{ Microclimate } \\
\hline Aspect & $4^{b}$ & Fisher's exact test \\
\hline Sunshine duration $(h)^{1}$ & metric & $\mathrm{GLM}^{2}, \mathrm{t}$ \\
\hline \multicolumn{3}{|l|}{ Vegetation height $(\mathrm{cm})^{3}$} \\
\hline Shrub layer $(<0.5 \mathrm{~m})$ & metric & $\mathrm{GLM}^{4}, \mathrm{MWU}$ \\
\hline Field layer & metric & GLM, MWU \\
\hline \multicolumn{3}{|l|}{ Vegetation cover $(\%)^{3}$} \\
\hline Shrub layer $(<0.5 \mathrm{~m})$ & metric & $\mathrm{GLM}^{4}, \mathrm{MWU}$ \\
\hline Field layer & metric & $\mathrm{GLM}^{5}, \mathrm{MWU}$ \\
\hline Mosses/lichens & metric & GLM, MWU \\
\hline Litter & metric & GLM, MWU \\
\hline \multicolumn{3}{|l|}{ Cover of bare ground (\%) } \\
\hline Bare soil & metric & MWU \\
\hline Gravel & metric & MWU \\
\hline Stones & metric & MWU \\
\hline Rocks & metric & MWU \\
\hline Total & metric & $\mathrm{GLM}^{5}, \mathrm{MWU}$ \\
\hline Host plant cover (\%) & metric & GLM, MWU \\
\hline
\end{tabular}

${ }^{1}$ Accuracy: $1 / 4 \mathrm{~h} ;{ }^{2}$ For most months, values of sunshine duration were inter-correlated. Therefore the mean of the values for all the months of a year was used; ${ }^{3}$ Height and cover of trees and taller shrubs were excluded from the analysis as they had zero values in more than $95 \%$ of the samples; ${ }^{4}$ Height and cover were inter-correlated. For GLM analysis, the principal component of both was used; ${ }^{5}$ Cover of field layer and total cover of bare ground were intercorrelated. For GLM analysis, the principal component of both was used; ${ }^{\mathrm{a} O c c u p i e d}=1$, unoccupied $=$ $0 ;{ }^{\text {b }}$ North $=1$, East $=2$, South $=3$, West $=4$.

Koschuh et al., 2005; Hermann, 2007). The larvae spend the winter within the egg shell and hatch in spring (Ebert \& Rennwald, 1991; Hermann, 2007).

Two potential host plants of $S$. spini occur in the pastures of the Aísa Valley: Dwarf buckthorn (Rhamnus pumila Turra) and Alpine buckthorn ( $R$. alpina L. ssp. alpina). R. pumila is a dwarf shrub with a reptant habit, mostly growing on calcareous rocks in mountainous regions in Southern Europe (Villar et al., 1997; Aeschimann et al., 2004). R. alpina is a shrub that can reach $4 \mathrm{~m}$ in height and grows on dry, base-rich and nutrient-poor soils in the mountains of South-western Europe (Villar et al., 1997; Aeschimann et al., 2004). On the southern slope of the Pyrenees both Rhamnus species mainly occur in the high mountain zone between 1200 and $2500 \mathrm{~m}$ a.s.l. (Villar et al., 1997).

\section{Sampling design}

In August 2010 we searched both of the potential host plants, Rhamnus pumila and R. alpina, for eggs of S. spini. We aimed to sample all aspects within the study area with the same intensity and therefore spent $45 \mathrm{~min}$ searching for eggs on north-, east-, south- and west-facing slopes, respectively. The time spent searching was measured using a stop-watch, which was on 
when searching a Rhamnus plant and off when walking to another plant.

For each host plant that was checked for eggs we noted its status [with eggs (hereafter referred to as "occupied") or without eggs (hereafter referred to as "unoccupied")], the number of egg batches found, the number of eggs per batch and several environmental parameters (Table 1). For each egg batch we noted its position on the host plant and the height above the surface of the ground (rock or ground). Vegetation structure was recorded in an area of $50 \times 50 \mathrm{~cm}$ (hereafter called "microhabitat") around each egg batch (Table 1). Potential daily sunshine duration was recorded for every month of the year using a horizontoscope (Tonne, 1954). Inclination and aspect were measured using a compass with inclinometer. The total amount of time spent sampling was one week.

\section{Data analysis}

If data were normally distributed (Shapiro-Wilk test) and variances were homogenous (Levene test), parameters on occupied and unoccupied host plants were compared using a $t$ test. Otherwise, a Mann-Whitney $U$ test was used. For categorical variables Fisher's exact test for small sample sizes was applied.

In addition to this, we used Generalized Linear Models (GLM) with different response variables (Table 1) for a more detailed analysis of the R. pumila microhabitats. All explanatory variables were checked for inter-correlations using Spearman's correlation coefficient before being entered into the models. Principal components were calculated and entered into the models for variables with correlation coefficients $>|0.5|$. As our count data showed overdispersion, we corrected the standard errors using quasi-Poisson GLMs. Non-significant predictors were excluded from the final models by stepwise backwardselection using the drop1 command. This command automati-

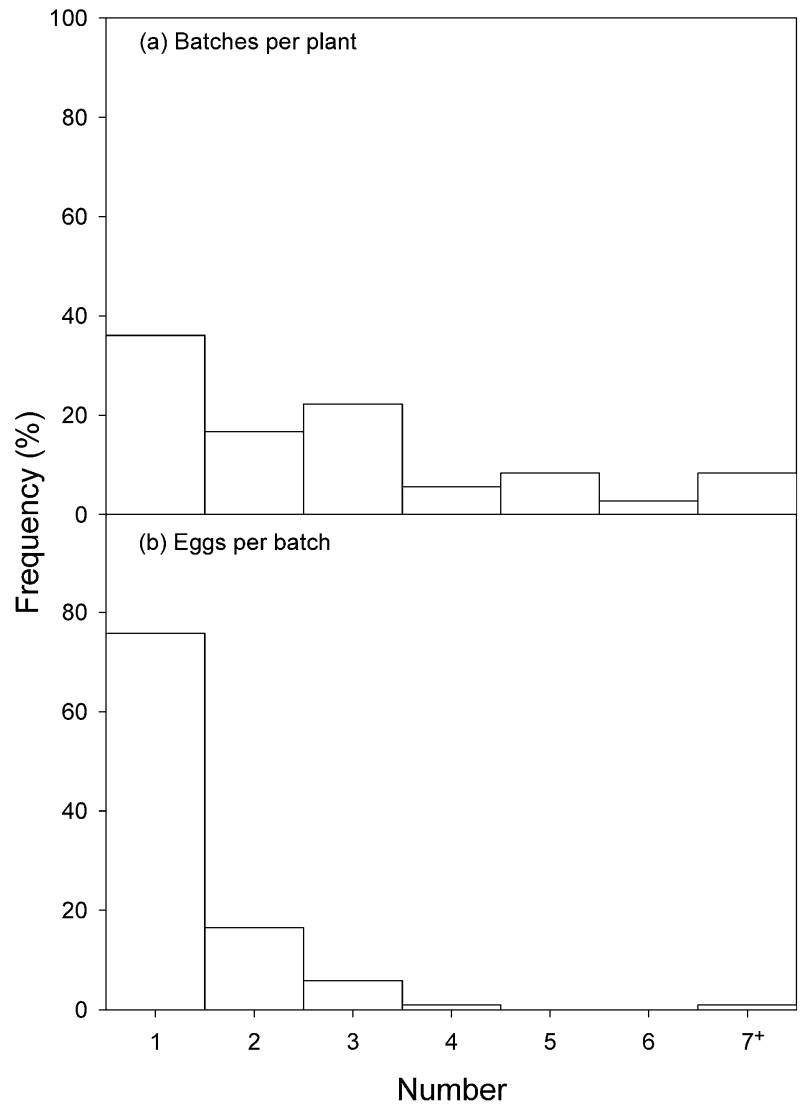

Fig. 2. Frequency distribution of the number of egg batches per plant (mean $\pm \mathrm{SE}=2.9 \pm 2.4$ ) (a) and eggs per batch (mean $\pm \mathrm{SE}=1.4 \pm 0.9)(\mathrm{b})\left(N_{\text {batches }}=103 ; N_{\text {eggs }}=142\right)$.

TABLE 2. Mean values \pm SD of all numerical environmental parameters on occupied and unoccupied host plants of Satyrium spini in the Aísa Valley. Comparison of mean or median values was done using $t$ test (t) and Mann-Whitney $U$ test (MWU), respectively; n.s. $=$ not significant, $* P<0.05, * * P<0.01, * * * P<0.001$.

\begin{tabular}{|c|c|c|c|c|c|}
\hline \multirow[b]{2}{*}{ Parameter } & \multicolumn{3}{|c|}{ Rhamnus pumila } & \multirow{2}{*}{$\begin{array}{l}R . \text { alpina } \\
\text { Occupied } \\
(\mathrm{N}=11)\end{array}$} & \multirow{2}{*}{$\frac{R . p . \text { vs. } R . a .^{1}}{P(\text { test })}$} \\
\hline & $\begin{array}{l}\text { Occupied } \\
(\mathrm{N}=36)\end{array}$ & $\begin{array}{l}\text { Unoccupied } \\
(\mathrm{N}=16)\end{array}$ & $P($ test $)$ & & \\
\hline \multicolumn{6}{|l|}{ Microclimate } \\
\hline Sunshine duration (h) & $6.5 \pm 1.7$ & $5.1 \pm 2.4$ & $* \mathrm{t}$ & $6.6 \pm 1.7$ & n.s. ${ }^{\mathrm{t}}$ \\
\hline \multicolumn{6}{|l|}{ Vegetation height $(\mathrm{cm})$} \\
\hline Shrub layer $(<0.5 \mathrm{~m})$ & $6.4 \pm 13.7$ & $3.4 \pm 9.8$ & n.s. ${ }^{\mathrm{MWU}}$ & $30.9 \pm 13.6$ & $* * * \mathrm{MWU}$ \\
\hline Field layer & $4.1 \pm 3.3$ & $4.8 \pm 4.3$ & n.s. ${ }^{\mathrm{MWU}}$ & $7.8 \pm 4.4$ & $* *$ MWU \\
\hline Mosses/lichens & $0.5 \pm 0.7$ & $0.4 \pm 0.6$ & n.s. ${ }^{\mathrm{MWU}}$ & $0.1 \pm 0.2$ & n.s. ${ }^{\mathrm{MWU}}$ \\
\hline Litter & $0.1 \pm 0.2$ & $0.3 \pm 1.0$ & n.s. ${ }^{\mathrm{MwU}}$ & $0.0 \pm 0.2$ & n.s. ${ }^{\mathrm{MWU}}$ \\
\hline \multicolumn{6}{|l|}{ Vegetation cover $(\%)$} \\
\hline Shrub layer $(<0.5 \mathrm{~m})$ & $1.5 \pm 4.1$ & $2.7 \pm 10.0$ & n.s. ${ }^{\mathrm{MWU}}$ & $26.4 \pm 16.6$ & $* * * \mathrm{MWU}$ \\
\hline Field layer & $16.5 \pm 19.2$ & $15.5 \pm 20.3$ & n.s. ${ }^{\mathrm{MWU}}$ & $27.5 \pm 27.3$ & n.s. ${ }^{\mathrm{MWU}}$ \\
\hline Mosses/lichens & $1.1 \pm 1.7$ & $2.7 \pm 0.9$ & n.s. ${ }^{\mathrm{MWU}}$ & $0.5 \pm 1.5$ & n.s. ${ }^{\text {MwU }}$ \\
\hline Litter & $0.4 \pm 1.7$ & $0.7 \pm 10.0$ & n.s. ${ }^{\mathrm{MWU}}$ & $2.7 \pm 9.0$ & n.s. ${ }^{\mathrm{MWU}}$ \\
\hline \multicolumn{6}{|l|}{ Cover of bare ground (\%) } \\
\hline Bare soil & $1.1 \pm 2.2$ & $0.2 \pm 0.6$ & $* \mathrm{MWU}$ & $0.9 \pm 3.0$ & n.s. ${ }^{\mathrm{MWU}}$ \\
\hline Gravel & $6.5 \pm 11.7$ & $4.8 \pm 10.0$ & n.s. ${ }^{\mathrm{MwU}}$ & $29.5 \pm 29.4$ & $* * \mathrm{MwU}$ \\
\hline Stones & $6.1 \pm 14.2$ & $1.6 \pm 2.4$ & n.s. ${ }^{\mathrm{MWU}}$ & $24.3 \pm 34.5$ & $* \mathrm{MWU}$ \\
\hline Rocks & $51.0 \pm 24.1$ & $59.5 \pm 27.0$ & n.s. ${ }^{t}$ & $14.1 \pm 26.4$ & $* * * \mathrm{MWU}$ \\
\hline Total & $65.3 \pm 22.6$ & $66.1 \pm 24.7$ & n.s. ${ }^{\mathrm{MWU}}$ & $71.6 \pm 23.4$ & n.s. ${ }^{\mathrm{MWU}}$ \\
\hline \multicolumn{6}{|l|}{ Host plant } \\
\hline Height (cm) & . & & . & $43.2 \pm 22.3$ & . \\
\hline Cover $(\%)$ & $16.8 \pm 11.2$ & $17.7 \pm 13.4$ & n.s. ${ }^{\mathrm{MWU}}$ & $31.8 \pm 17.5$ & $* *$ MWU \\
\hline
\end{tabular}

${ }^{1}$ Occupied Rhamnus pumila and occupied R. alpina plants were compared. 
(a) Occupied and unoccupied host plants

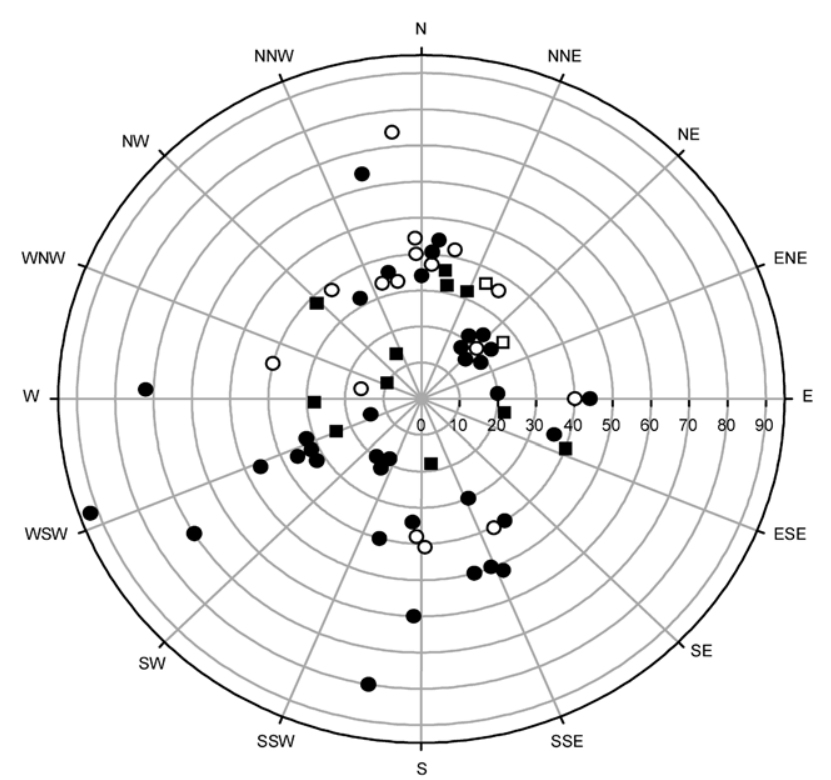

- Rhamnus alpina

- 0 Rhamnus pumila (b) Egg batches

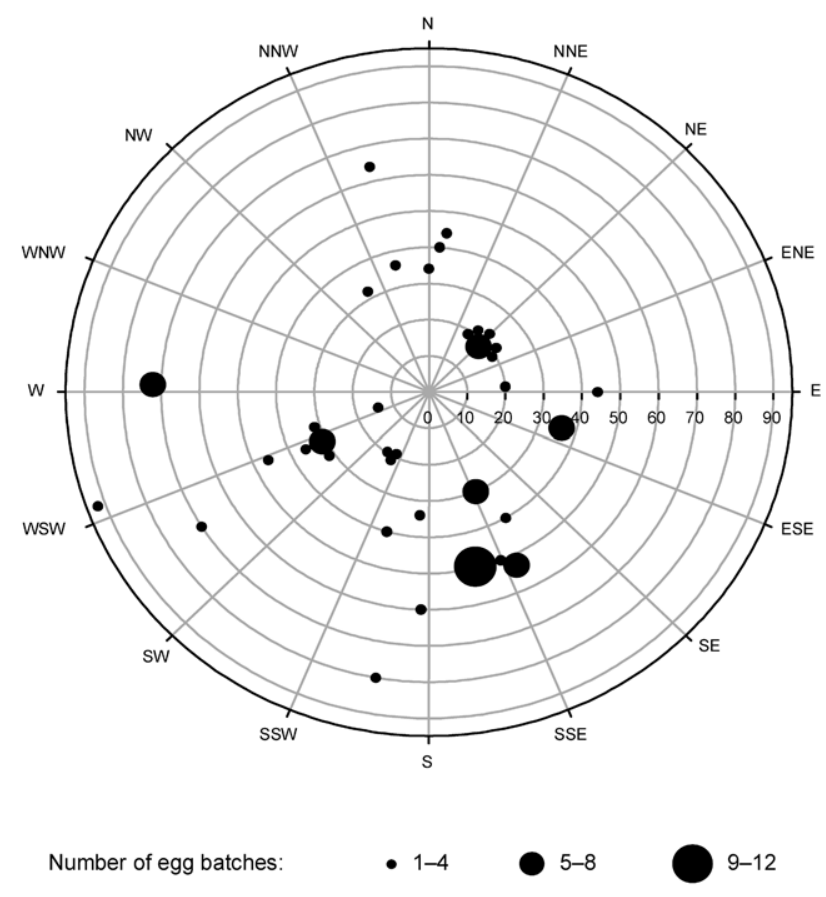

Fig. 3. Polar plot of aspect and slope $\left(^{\circ}\right)$ where Rhamnus host plants grew that were used for oviposition by Satyrium spini (black symbols) and those that were not (white symbols) (a) and the number of egg batches per Rhamnus pumila plant (b).

cally drops each explanatory variable in turn, and each time assesses the significance of the dropped variable by likelihood ratio tests (type III tests). Only explanatory variables significant at the $5 \%$ level were retained in the final models.

Significance tests and correlation analyses were performed using SigmaPlot 11.0 and GLM analyses were conducted in R 2.12.2 (R Development Core Team, 2011).

\section{RESULTS}

In total we surveyed $52 R$. pumila (36 occupied vs. 16 unoccupied) and $13 R$. alpina plants (11 vs. 2) (Table 2). Altogether we found $103 \mathrm{egg}$ batches on 36 R. pumila and 40 on $11 R$. alpina (Fig. 2, Table 2). Usually, occupied host plants had one up to three batches $(75 \%$ of the cases); four to twelve batches per host plant rarely occurred (25\%) (Fig. 2). Females usually laid their eggs singly $(76 \%)$ or in small groups of two or three eggs $(22 \%)$. Egg batches of four to eight eggs were rare exceptions $(2 \%)$. Mean size of the egg batches did not differ between $R$. pumila (mean $\pm \mathrm{SD}=1.4 \pm 0.9)$ and $R$. alpina (mean $\pm \mathrm{SD}=1.5 \pm 0.9)$ (Mann-Whitney $U$ test: $U=$ 1881.0, $P=0.30)$. Eggs were deposited on twigs and in twig forks. Due to its reptant growth, batches on $R$. pumila were always situated very close to the surface of the ground (mean $\pm \mathrm{SD}=2.0 \pm 2.1 \mathrm{~cm}$ ). Eggs on $R$. alpina were found from 1 to $57 \mathrm{~cm}$ above ground with three quarters of them between 5 and $15 \mathrm{~cm}$ (mean \pm SD $=10.5 \pm 10.0 \mathrm{~cm})$. Eggs were laid at significantly different heights on the two host plants (Mann-Whitney $U$ test: $U=445.5, P<0.001)$.

Typically, the microhabitats of occupied $R$. pumila were very sunny and sparsely vegetated rocks, solitary boulders or screes in the pastures (Fig. 1b, Table 2). The sites were dominated by bare rocks and vegetation usually covered less than one fifth of the ground. Microhabitats of occupied $R$. pumila were - compared to unoccupied ones - characterized by a significantly longer sunshine duration and cover of bare soil. Microhabitats of occupied $R$. alpina had similar characteristics and were mostly found on screes and river banks (Fig. 1c, Table 2). However, shrub height and cover, field layer height, hostplant cover and the cover of gravel and stones were significantly higher, while that of rocks was significantly lower.

Although occupied plants of both Rhamnus species were found in areas with a wide range of aspects and inclinations, most occupied R. pumila occurred on east-, south- and west-facing slopes (Fig. 3a, Table 3). This difference in aspect between occupied and unoccupied $R$. pumila plants was slightly not significant $(P=0.06)$. However, the number of batches per $R$. pumila plant was

TABLE 3. Absolute and relative frequencies of the nominal variable aspect in occupied and unoccupied Rhamnus pumila microhabitats. Results of Fisher's exact test using absolute frequencies: occupied vs. unoccupied: $P=0.06$; number of egg batches vs. unoccupied: $P<0.001$.

\begin{tabular}{lcccccc}
\hline \multirow{2}{*}{ Aspect } & \multicolumn{2}{c}{$\begin{array}{c}\text { Occupied } \\
(\mathrm{N}=36)\end{array}$} & \multicolumn{2}{c}{$\begin{array}{c}\text { Unoccupied } \\
(\mathrm{N}=16)\end{array}$} & \multicolumn{2}{c}{$\begin{array}{c}\text { Egg batches } \\
(\mathrm{N}=103)\end{array}$} \\
\cline { 2 - 7 } & $\mathrm{N}$ & $\%$ & $\mathrm{~N}$ & $\%$ & $\mathrm{~N}$ & $\%$ \\
\hline North & 6 & 16.7 & 9 & 56.3 & 9 & 8.7 \\
East & 9 & 25.0 & 2 & 12.5 & 23 & 22.3 \\
South & 12 & 33.3 & 3 & 18.8 & 44 & 42.7 \\
West & 9 & 25.0 & 2 & 12.5 & 27 & 26.2 \\
\hline
\end{tabular}


TABLE 4. Results of the Generalized Linear Model analysis used to determine the association of several environmental parameters (predictor variables, Table 1) with the presence of egg batches in Rhamnus pumila microhabitats (a) and the number of egg batches per $R$. pumila plant (b). Non-significant predictors were excluded from the final model by stepwise backward selection $(P>0.05)$. Sample sizes: 36 occupied microhabitats, 16 unoccupied microhabitats, 103 egg batches.

\begin{tabular}{|c|c|c|c|c|}
\hline Variable & $\begin{array}{l}\text { Esti- } \\
\text { mate }\end{array}$ & SE & $Z$ & $P$ \\
\hline \multicolumn{5}{|l|}{ a) Presence of egg batches } \\
\hline Sunshine duration & 0.030 & 0.014 & 2.213 & $<0.05$ \\
\hline \multicolumn{5}{|l|}{ Pseudo $R^{2}$ [Nagelkerke's] $=0.14$} \\
\hline \multicolumn{5}{|l|}{ b) Egg batches/plant } \\
\hline Sunshine duration & 0.021 & 0.007 & 2.930 & $<0.01$ \\
\hline Pseudo $R^{2}$ [Nagelkerke's] $=0.36$ & & & & \\
\hline
\end{tabular}

significantly higher on plants in those aspects than on north-facing slopes (Fig. 3b, Table 3).

The importance of unshaded sites that receive large amounts of direct solar radiation is confirmed by the results of the GLM analyses (Table 4). Potential daily sunshine duration was the only significant parameter explaining the presence of egg batches on $R$. pumila [Pseudo $R^{2}$ (Nagelkerke's) $=0.14$ ] and the number of egg batches per $R$. pumila plant [Pseudo $R^{2}$ (Nagelkerke's) = $0.36]$.

\section{DISCUSSION}

This study on the oviposition habitats of $S$. spini in high mountain common pastures of the Spanish Pyrenees showed that females used $R$. pumila and R. alpina for oviposition. Both species represent novel host plant records for Spain (cf. Munguira et al., 1997). Occupied plants grew mostly at sparsely vegetated grassland sites with large patches of bare rocks, stones or gravel. Most of the egg batches were laid close to the ground, on the reptant $R$. pumila directly above the rock surface (mostly $<2 \mathrm{~cm}$ ) and on the taller $R$. alpina mostly within $15 \mathrm{~cm}$ above ground. In three quarters of the cases the batches contained only one egg. The number of batches per R. pumila plant was highest on east-, south- and west-facing slopes and least on north-facing slopes. Presence of eggs and the number of egg batches per $R$. pumila plant were best explained by a long sunshine duration.

These findings indicate that a warm microclimate is of crucial importance for $S$. spini. Although the two host plants of $S$. spini have completely different growth forms, all egg-laying sites exhibit roughly the same characteristics that ensure favourable microclimatic conditions. Based on the results of this study we conclude that there are three main factors that contribute to the relatively high temperatures in the oviposition habitats of S. spini:

(i) By preferring sunny locations on east-, south- and west-facing slopes, females make sure that the eggs and larvae receive large amounts of direct solar radiation. (ii) Large patches of bare ground around the host plants further warm up the near-ground air layer (cf. Stoutjesdijk \& Barkman, 1992).

(iii) The eggs are laid close to the ground in the boundary layer where wind speed is lowest and air temperatures are highest (cf. Porter, 1992).

The importance of a warm microclimate for the immature stages has been described for many thermophilous butterfly species (García-Barros \& Fartmann, 2009) and has already been shown for S. spini in Central European lowlands and low mountain ranges (Koschuh et al., 2005; Hermann, 2007; Löffler et al., 2013). In our study area, however, warm microhabitats are likely to be even more important than in Central Europe. At the lower altitudes in Central Europe, where the climate is mild (Ellenberg \& Leuschner, 2010), this species lays its eggs at heights of up to $1.3 \mathrm{~m}$ above the ground and the occurrence of bare ground, rocks or gravel is not a prerequisite for egglaying (Löffler et al., 2013). We assume that the preference for unusually warm microhabitats is explained by the harsh climatic conditions near its altitudinal range limit in the Pyrenees. The growing season is rather short with 80-150 days (Aldezabal Roteta, 2001), and the mean summer temperature of $13.5^{\circ} \mathrm{C}$ is relatively low (given for an altitude of $1780 \mathrm{~m}$ a.s.l.) (Badía Villas et al., 2002). Some other studies also indicate that butterflies compensate for the cooler climate near their cool range margins by occupying relatively narrow and hot niches (Thomas, 1993; Thomas et al., 1998; Merrill et al., 2008).

S. spini is known to deposit its eggs usually in small batches (Hermann, 2007). Koschuh et al. (2005) and Löffler et al. (2013) showed for low mountain ranges in Eastern Austria and lowlands in Central Germany, respectively, that $25 \%$ of the batches consisted of one egg and $75 \%$ of two or more eggs. Surprisingly, in our study the ratio was reversed with $76 \%$ of the eggs laid singly. Dispersing the eggs in space rather than concentrating them in a few localities has often been considered as a strategy of risk-spreading (García-Barros \& Fartmann, 2009). In line with this, we interpret the oviposition of single eggs by a female in our study area as a strategy to increase the survival rate of the offspring under unfavourable and poorly predictable climatic conditions. The climate in the high mountain zone of the Spanish Pyrenees is characterised by relatively short and cool summers, long and cold winters (see above), high velocity winds in winter causing snowdrift and damaging the vegetation (pers. observ.) and an overall large inter-annual variation. In contrast, weather conditions at the lower altitudes in Central Europe are not as harsh and more predictable. For Hamearis lucina, small egg batches are also thought to constitute a risk-spreading strategy to cope with unfavourable climatic conditions along a geographic gradient (Anthes et al., 2008). However, to verify this assumption it is necessary to undertake further studies on batch size and survival rates of $S$. spini eggs and larvae along a climatic gradient. 


\section{Implications for conservation}

Based on the results of this study we conclude that the preservation of open grasslands with small buckthorn plants growing in very sunny and warm locations is crucial for the long-term survival of $S$. spini. Abandonment of common pastures in the Spanish Pyrenees with subsequent shrub encroachment and reforestation would lead to shading of the host plants and a loss of habitat for $S$. spini (cf. Löffler et al., 2013) and probably many other thermophilous grassland species (Steffan-Dewenter \& Tscharntke, 2002; WallisDeVries et al., 2002; Stefanescu et al., 2011). Areas above the climatic timberline might be too cold and suitable habitats at lower elevations in the Pyrenees, where the opposed processes of agricultural intensification and abandonment are even more accentuated than in high mountain areas (García-Ruiz \& LasantaMartínez, 1990; Lasanta-Martínez et al., 2005), are probably scarce. Sites where the vegetation structure remains open without any kind of management (e.g. floodplains, extremely steep slopes) are few in number and mostly of small size (pers. observ.).

The best way to maintain an open landscape and preserve the species-rich and structurally diverse vegetation of the high mountain common pastures is the traditional combination of sheep and cattle grazing. Sheep are known to be selective grazers and have a homogenising effect on the vegetation (Rook et al., 2004), but also contribute to the maintenance of some specific plant species and communities of high conservation value (Sebastià et al., 2008). Cattle in contrast do not select particular plant species and thus, enhance vegetation heterogeneity (Sebastià et al., 2008) and are effective in controlling shrub encroachment even at moderate stocking densities (Casasús et al., 2007). Several recent studies have documented positive effects of cattle grazing on species richness of plants and insects (e. g. Pykälä, 2003; Pöyry et al., 2004; WallisDeVries et al., 2007). Besides, cattle are the farm animals preferred by local farmers for economic reasons (García-Ruiz \& Lasanta-Martínez, 1990) and if conservation policies are to be effective they should be based on economically profitable measures. Where livestock grazing alone is not sufficient to counteract reforestation, mechanical removal of shrubs and trees should be done like in former (and partially recent) times, when woody species were cut by farmers for firewood and in order to keep the pastures open.

ACKNOWLEDGEMENTS. We would like to thank G. Hermann, M. Konvicka and two anonymous reviewers for valuable comments on an earlier version of the manuscript.

\section{REFERENCES}

Abós CAStel F.-P. 1988: Mariposas diurnas del Parque Nacional de Ordesa y Monte Perdido. Diputación General de Aragón, Zaragoza, $188 \mathrm{pp}$.

Aeschimann D., Lauber K., Moser D.M. \& Theurillat J.-P. 2004: Flora Alpina. Vol. 1. Haupt Verlag, Stuttgart, 1159 pp.

Aldezabal Roteta A. 2001: El sistema de pastoreo del Parque Nacional de Ordesa y Monte Perdido. Publicaciones del Consejo de Protección de la Naturaleza de Aragón, Zaragoza, 317 pp.
Anthes A., Fartmann T. \& Hermann G. 2008: The Duke of Burgundy butterfly and its dukedom: larval niche variation in Hamearis lucina across Central Europe. J. Insect Conserv. 12: $3-14$.

Badía Villas D., García-González R. \& Martí Dalmau C. 2002: Clasificación de suelos en pastos alpinos de Aísa y Ordesa (Pirineo central). Edafología 9: 11-22.

BezÁK P. \& Halada L. 2010: Sustainable management recommendations to reduce the loss of agricultural biodiversity in the mountain regions of NE Slovakia. Mount. Res. Devel. 30: 192-204.

CARAVEl H. 2000: A comparative analysis on intensification and extensification in mediterranean agriculture: dilemmas for LFAs policy. J. Rural Stud. 16: 231-242.

Casasús I., Bernués A., Sanz A., Villalba D., Riedel J.L. \& Revilla R. 2007: Vegetation dynamics in Mediterranean forest pastures as affected by beef cattle grazing. Agric. Ecosyst. Environ. 121: 365-370.

Ebert G. \& Rennwald E. 1991: Die Schmetterlinge BadenWürttembergs, Band 2, Tagfalter II. Eugen Ulmer, Stuttgart, $535 \mathrm{pp}$.

Ellenberg H. \& Leuschner C. 2010: Vegetation Mitteleuropas mit den Alpen in ökologischer, dynamischer und historischer Sicht. Eugen Ulmer, Stuttgart, 535 pp.

FARTMANN T. 2004: Die Schmetterlingsgemeinschaften der Halbtrockenrasen-Komplexe des Diemeltales. Biozönologie von Tagfaltern und Widderchen in einer alten Hudelandschaft. Abh. Westfäl. Mus. Naturk. 66(1): 1-256.

Foley J.A., DeFries R., Asner G.P., Barford C., Bonan G., Carpenter S.R., Chapin F.S., Coe M.T., Daily G.C., Gibbs H.K., Helkowski J.H., Holloway T., Howard E.A., Kucharik C.J., Monfreda C., Patz J.A., Prentice I.C., Ramankutty N. \& SNYDER P.K. 2005: Global consequences of land use. Science 309: 570-574.

García-Barros E. \& Fartmann T. 2009: Butterfly oviposition: sites, behaviour and modes. In Settele J., Shreeve T., Konvicka M. \& Van Dyck H. (eds): Ecology of Butterflies in Europe. Cambridge University Press, Cambridge, 513 pp.

García-Barros E., Munguira M.L., Cano J.M., Benito H.R., García-Pereira P. \& Maravalhas E.S. 2004: Atlas de las mariposas diurnas de la Península Ibérica e islas Baleares (Lepidoptera: Papilionoidea \& Hesperioidea). Monogr. Soc. Entomol. Aragon. 11: 1-228.

García-González R., Gómez D. \& Remón J.L. 1991: Application of vegetation maps to the study of grazing utilization: a case in the western Pyrenees. Phytocoenosis 3: 251-256.

García-González R., Alados I.C.L., Bueno G., Fillat F., Gartzia M., Gómez García D., Komac B., Marinas A. \& SAINT-JeAn N. 2008: Valoración ecológica y productiva de los pastos supraforestales en el Parque Nacional de Ordesa y Monte Perdido. In Ministerio de Medio Ambiente (ed.): Proyectos de investigación en parques nacionales: 2003-2006: 105-128.

García-Ruiz J. \& Lasanta-Martínez T. 1990: Land-use changes in the Spanish Pyrenees. Mount. Res. Devel. 10: 267-279.

García-Ruiz J.M., Lasanta T., Ruiz-Flaño P., Ortigosa L., White S., GonzÁles C. \& Martí C. 1996: Land-use changes and sustainable development in mountain areas: a case study in the Spanish Pyrenees. Landsc. Ecol. 11: 267-277.

Gómez D., Sesé J.A. \& Villar L. 2003: The vegetation of the alpine zone in the Pyrenees. In Nagy L., Grabherr G., Körner C. \& Thompson D.B.A. (eds): Alpine Biodiversity in Europe. Ecological Studies 167. Springer, Berlin, Heidelberg, 477 pp.

Henle K., Alard D., Clithero J., Cobb P., Firbank L., Kull T., McCracken D., Moritz R.F.A., Niemelä J., Rebane M., 
Wascher D., Watt A. \& Young J. 2008: Identifying and managing the conflicts between agriculture and biodiversity conservation in Europe - a review. Agric. Ecosyst. Environ. 124: $60-71$.

HermanN G. 2007: Tagfalter suchen im Winter - Zipfelfalter, Schillerfalter und Eisvögel. Searching for butterflies in Winter - Hairstreaks, Purple Emperos, Poplar Admirals \& White Admirals. Books on Demand $\mathrm{GmbH}$, Norderstedt, 224 pp.

Huemer P. 2004: Die Tagfalter Südtirols. Veröffentlichungen des Naturmuseums Südtirol No. 2. Folio Verlag, Wien, 232 pp.

ISERN-VALLVERDÚ J. 1990: A quantitative ecology of Orthopteran communities on Pyrenean grasslands above timberline (Huesca, Spain). Bol. Sanid. Veget. Plagas 20: 311-320.

Kleijn D., Kohler F., Báldi A., Batáry P., Concepción E.D., Clough Y., Díaz M., Gabriel D., Holzschum A., Knop E., Kovács A., Marshall E.J.P., Tscharntke T. \& Verhulst J. 2009: On the relationship between farmland biodiversity and land-use intensity in Europe. Proc. R. Soc. (B) 276: 903-909.

Koschun A., Savas V. \& Gepp J. 2005: Winter-Eifunde von Zipfelfalterarten (Lepidoptera: Lycaenidae) in Graz und Umland (Steiermark, Österreich) - Konsequenzen für den Naturschutz. Naturschutz Landschaftspl. 37(2): 46-53.

Lasanta-Martínez T., Vicente-Serrano S. \& Cuadrat-Prats J. 2005: Mountain Mediterranean landscape evolution caused by the abandonment of traditional primary activities: a study of the Spanish Central Pyrenees. Appl. Geogr. 25: 47-65.

LÖFfler F., Stuhldreher G. \& Fartmann T. 2013: How much care does a shrub-feeding hairstreak butterfly (Satyrium spini) need in calcareous grasslands? Eur. J. Entomol. 110 [in press].

MacDonald D., Crabtree J.R., Wiesinger G., Dax T., Stamou N., Fleury P., Gutiérrez Lazpita J. \& Gibon A. 2000: Agricultural abandonment in mountain areas of Europe: environmental consequences and policy response. J. Environ. Manag. 59: 47-69.

Merrill R.M., Gutiérrez D., Lewis O.T., Gutiérrez J., Díez S.B. \& WiLSON R.J. 2008: Combined effects of climate and biotic interactions on the elevational range of a phytophagous insect. J. Anim. Ecol. 77: 145-155.

Munguira M.L., García-Barros E. \& Martín J. 1997: Plantas nutricias de los licénidos y satirinos españoles (Lepidoptera: Lycaenidae y Nymphalidae). Bol. Asoc. Esp. Entomol. 21 (1-2): 29-53.

Pimm S.L., Russel G.J., Gittleman J.L. \& Brooks T.M. 1995: The future of biodiversity. Science 269: 347-350.

PORTER K. 1992: Eggs and egg-laying. In Dennis R.L.H. (ed.): The Ecology of Butterflies in Britain. Oxford University Press, Oxford, pp. 46-72.

Poyatos R., Latron J. \& Llorens P. 2003: Land use and land cover change after agricultural abandonment - the case of a Mediterranean mountain area (Catalan Pre-Pyrenees). Mount. Res. Devel. 23: 362-368.

Pöyry J., Lindgren S., Salminen J. \& KuUssaari M. 2004: Restoration of butterfly and moth communities in semi-natural grasslands by cattle grazing. Ecol. Applicat. 14: 1656-1670.

PYKÄLÄ J. 2003: Effects of restoration with cattle grazing on plant species composition and richness of semi-natural grasslands. Biodivers. Conserv. 12: 2211-2226.

R Development Core Team 2011: R: A Language and Environment for Statistical Computing. R Foundation for Statistical Computing, Vienna.

Rook A.J., Dumont B., Isselstein J., Osoro K., WallisDeVries M.F., Parente G. \& Mills J. 2004: Matching type of live- stock to desired biodiversity outcomes in pastures - a review. Biol. Conserv. 119: 137-150.

Sala O.E., Chapin III F.S., Armesto J.J., Berlow E., Bloomfield J., Dirzo R., Huber-Sanwald E., Huenneke L.F., Jackson R.B., Kinzig A., Leemans R., Lodge D.M., Mooney H.A., Oesterheld M., LeRoy Poff N., Sykes M.T., Walker B.H., WalKer M. \& Wall D.H. 2000: Global biodiversity scenarios for the year 2100. Science 287: 1770-1774.

SÁnchez D. (ed.) 2007: La Jacetania. Red Natural de Aragón. Prames-CAI-G de Aragón, Zaragoza, 215 pp.

Sebastià M.T., de Bello F., Puig L. \& Taull M. 2008: Grazing as a factor structuring grasslands in the Pyrenees. Appl. Veget. Sci. 11: 215-222.

Stefanescu C., Torre I., Jubany J. \& PÁramo F. 2011: Recent trends in butterfly populations from north-east Spain and Andorra in the light of habitat and climate change. $J$. Insect Conserv. 15: 83-93.

StefFan-Dewenter I. \& TscharntKe T. 2002: Insect communities and biotic interactions on fragmented calcareous grasslands - a mini review. Biol. Conserv. 104: 275-284.

StoutjesdiJk P. \& Barkman J.J. 1992: Microclimate, Vegetation and Fauna. Opulus Press, Uppsala, 216 pp.

TASSER E. \& TAPPEINER U. 2002: Impact of land use changes on mountain vegetation. Appl. Veget. Sci. 5: 173-184.

THOMAS J.A. 1993: Holocene climate change and warm manmade refugia may explain why a sixth of British butterflies possess unnatural early-successional habitats. Ecography 16: 278-284.

Thomas J.A., Simcox D.J., Wardlaw J.C., Elmes G.W., HochBERG M.E. \& ClaRKe R.T. 1998: Effects of latitude, altitude and climate on the habitat and conservation of the endangered butterfly Maculinea arion and its Myrmica ant hosts. J. Insect Conserv. 2: 39-46.

Tolman T. \& Lewington R. 1998: Die Tagfalter Europas und Nordwestafrikas. Kosmos, Stuttgart, 319 pp.

TonNe F. 1954: Besser Bauen mit Besonnungs- und TageslichtPlanung. Karl Hoffmann, Schorndorf, 41 pp.

Van SwaAy C., Warren M. \& Lois G. 2006: Biotope use and trends of European butterflies. J. Insect Conserv. 10: 189-209.

Vicente-Serrano S.M., Lasanta T. \& Romo A. 2005: Analysis of spatial and temporal evolution of vegetation cover in the Spanish Central Pyrenees: role of human management. Environ. Manag. 34: 802-818.

Villar L., Sesé J.A. \& Ferrández J.V. 1997: Atlas de la Flora del Pirineo Aragonés. Vol. 1. Consejo de Protección de la Naturaleza de Aragón \& Instituto de Estudios Altoaragoneses, Huesca, $\mathrm{XCII}+648$ pp.

WallisDeVries M.F., Poschlod P. \& Willems J.H. 2002: Challenges for the conservation of calcareous grasslands in northwestern Europe: integrating the requirements of flora and fauna. Biol. Conserv. 104: 265-273.

WallisDeVries M.F., Parkinson A.E., Dulphy J.P., SAyer M. \& DiANA E. 2007: Effects of livestock breed and grazing intensity on biodiversity and production in grazing systems. 4. Effects on animal diversity. Grass Forage Sci. 62: 185-197.

Watt W.B. \& BogGS C.L. 2003: Synthesis: butterflies as model systems in ecology and evolution - present and future. In Boggs C.L., Watt W.B. \& Ehrlich P.R. (eds): Butterflies Ecology and Evolution Taking Flight. The University of Chicago Press, Chicago, 736 pp.

WeIDEmann H.J. 1982: Gedanken zum Artenschutz. 2. Über Mängel der herkömmlichen Lepidopterologie - ein Liebhaberentomologe gibt Denkanstöße. Entomol. Z. 92(8): 97-111.

Received February 29, 2012; revised and accepted April 26, 2012 